\title{
TBX4 wt Allele
}

National Cancer Institute

\section{Source}

National Cancer Institute. TBX4 wt Allele. NCI Thesaurus. Code C106322.

Human TBX4 wild-type allele is located within 17q21-q22 and is approximately $33 \mathrm{~kb}$ in length. This allele, which encodes T-box transcription factor TBX4 protein, is involved in both transcriptional regulation and limb formation. Mutation of the gene is associated with small patella syndrome. 